PROCEDIA

Studi Kasus dan Intervensi Psikologi

ISSN:2302-1462

Volume 6(1) 1-9, Januari 2018

DOI: $10.22219 /$ procedia.v6i1.12627

\title{
Solution focused therapy untuk memperbaiki komunikasi pada ayah dan anak
}

Firdaus Yuni Hartatik, Universitas Muhammadiyah Malang, Malang, Indonesia

Korespondonesi:

Firdaus Yuni Hartatik, Universitas Muhammadiyah Malang, Malang, firdausyunihartatik@gmail.com

\section{Riwayat artikel}

Naskah diterima:

$16 / 10 / 2017$

Revisi diterima:

$04 / 12 / 2017$

Naskah disetujui:

$12 / 12 / 2017$

\begin{abstract}
Abstrak
Klien dalam kasus ini adalah seorang ayah dan kedua anak perempuannya yang memiliki masalah utama berupa komunikasi yang tidak tepat dan menyebabkan kurang efektifnya pencarian jalan keluar dalam mengatasi permasalahan keluarga.Asesmen dalam kasus ini menggunakan metode wawancara dan observasi pada klien.Hasil asesmen menunjukkan bahwa bentuk komunikasi yang kurang tepat antar klien menyebabkan tidak tersampaikannya informasi dengan benar serta menimbulkan kesalahan dalam mempersepsi informasi tersebut dan pada akhirnya mempengaruhi atribusi masing-masing klien.Intervensi pada kasus ini menggunakan teknik solution focused therapy, yang dilaksanakan dalam lima(5) sesi dan bertujuan untuk memperbaiki pola komunikasi antar klien dalam hal penanganan terhadap permasalahan salah satu anggota keluarga (ibu). Setelah melalui rangkaian intervensi, diperoleh hasil bahwa ayah dan anak lebih mengetahui kebutuhan utama ibu/istri serta keinginan dan maksud masing-masing klien (ayah, anak). Kesadaran akan pentingnya komunikasi yang tepat dan efektif secara langsung berpengaruh terhadap pengambilan keputusan dalam keluarga terkait penanganan ibu. Dengan membaiknya komunikasi antar klien, pengambilan keputusan dalam keluarga menjadi lebih optimal.

Kata kunci: Solution focused therapy, komunikasi, keluarga.
\end{abstract}

\section{Latar Belakang}

Keluarga merupakan unit terkecil dari kehidupan bermasyarakat yang sekaligus merupakan tempat utama berkembangnya anggota keluarga baik secara fisik, emosi, spiritual dan sosial.Proses yang berlangsung dalam keluarga mempengaruhi seluruh anggota keluarga yang meliputi hubungan antar pasangan, hubungan orangtua dengan anak serta hubungan antara anak dengan anak yang lain(Leiber, Mack, \& Featherstone, 2009). Komunikasi menjadi salah satu faktor utama yang menjadi aspek terpenting dalam hubungan keluarga.Komunikasi 
yang efektif adalah karakteristik penting dari keluarga yang kuat dan sehat. Penelitian mengidentifikasi komunikasi sebagai blok bangunan penting dari perkawinan, hubungan orangtua-anak, dan saudara kandungyang kuat(Luciana, Constantineanu, Ielics, \& Popa, 2012).

Komunikasi dalam keluarga sangat penting karena memungkinkan anggota untuk mengekspresikan kebutuhan, keinginan, dan keprihatinan mereka satu sama lain. Melalui komunikasi, anggota keluarga dapat menyelesaikan masalah yang tak terhindarkan yang muncul dalam semua keluarga.Komunikasi yang terbuka dan jujur menciptakan suasana yang memungkinkan anggota keluarga untuk mengekspresikan perbedaan mereka serta cinta dan kekaguman satu sama lain(Offrey \& Rinaldi, 2014). Sementara komunikasi yang buruk, tidak jelas dan tidak langsung dapat menyebabkan banyak masalah keluarga, termasuk konflik keluarga yang berlebihan, pemecahan masalah yang tidak efektif, kurangnya keintiman, dan ikatan emosional yang lemah(Davidson \& Cardemil, 2009; Luciana et al., 2012).

Permasalahan mengenai komunikasi yang tidak langsung atau indirect communication cukup sering terjadi pada lingkungan keluarga masyarakat Indonesia, dimana budaya masih kental dengan aturan-aturan tatakrama yang terkadang menimbulkan efek negatif pada hubungan keluarga.Dalam keluarga, masih sering ditemui anggota keluarga yang lebih memilih diam dan memendam perasaan daripada menyampaikan langsung opininya tentang sesuatu. Seringkali juga, anggota keluarga lebih suka menunjukkan maksud melalui sikap dan perbuatan bukannya menyampaikan dengan jelas apa yang diinginkan. Jika terus terjadi, hal ini tentu dapat menimbulkan permasalahan jika anggota keluarga lainnya gagal memahami apa maksud sebenarnya yang ingin disampaikan. Terlebih saat keluarga memiliki permasalahan yang harus segera dicari jalan keluarnya bersama-sama.Bukan tidak mungkin jika anggota keluarga terbiasa berkomunikasi secara indirect, membuat permasalahan keluarga menjadi lebih buruk dan tidak menemukan penyelesaian.Untuk itu, keluarga perlu melakukan konseling atau terapi bersama guna menyelesaikan permasalahan komunikasi tersebut, lebih lanjut ketika kesalahan komunikasi menyebabkan tidak terselesaikannya permasalahan keluarga secara cepat dan tepat.

Salah satu terapi yang efektif untuk mengatasi masalah komunikasi dalam keluarga dikenal dengan solution focused therapy (SFT). Terapi yang berfokus pada solusi berbasis kekuatan model yang membantu klien menyelesaikan masalah saat ini dengan membangun sumber daya yang ada dan solusi efektif yang diterapkan sebelumnya(Castro \& Guterman, 2008) dengan asumsi dasar bahwa klien mengetahui apa yang terbaik untuk mereka (Trepper, Dolan, Mccollum, \& Nelson, 2006). Tujuan dari pemberian intervensi SFT pada kasus ini adalah untuk mengubah gayakomunikasi antara ayah dan anak yang selama ini kurang mampu berkembang dengan baik sehingga dapatmenghasilkan komunikasi yang lebih adaptif yang kemudian dapat memudahkan keluarga dalam menemukan jalan keluar dari berbagai permasalahan dengan lebih mudah.

\section{Metode Asesmen}

Metode asessmen yang digunakan dalam kasus ini adalah (1) Wawancara klinis, yaitu wawancara yang dilakukan guna mengumpulkan informasisecara mendalam kepada anggota keluarga yang terlibat mengenai dinamika permasalahan yangterjadi, dan (2) Observasi, dilakukan guna mengetahui bagaimana pola komunikasi dan interaksi antar anggotakeluarga.

\section{Presentasi Kasus}

Klien merupakan keluarga yang beranggotakan sembilan orang, terdiri dari ayah, ibu dan tujuh orang anak. Keenam anak pertama sudah berkeluarga dan tinggal di kota yang berbeda. Dua anak terakhir adalah perempuan yang saat ini belum menikah namun juga tinggal di kota yang berbeda dengan orangtua. Saat ini, Y (suami/ayah) tinggal berdua dengan SM (istri/ibu) di kecamatan Pare kabupaten Kediri.Sementara dua anak perempuan terakhirnya (L dan G) 
tinggal di Malang.Seluruh anak dan cucunya sudah biasa bergantian untuk menjenguk ayah dan ibu di Pare.Meski lebih sering dijenguk, terkadang ayah dan ibu juga berkunjung ke rumah anak-anak mereka. Di Pare, ayah yang sudah pensiun mengisi hari-harinya dengan menggarap sawah dan beternak ikan di kolam pancing miliknya. Ia mengatakan bahwa anak dan cucunya sangat menyukai memancing saat sedang pulang ke Pare.

Permasalahan mulai muncul ketika tiga tahun yang lalu ibu di diagnosa mengalami demensia.Ia sering lupa meletakkan uang belanja yang setiap bulan diberikan oleh ayah (gaji pensiun). Bahkan semakin bertambah parah dengan mengatakan bahwa ayah belum memberikan uang belanja.Ibu juga pernah beberapa kali pergi keluar rumah, namun pulang ke rumah diantar oleh tetangga.Selain itu, ibu sering bertanya kepada ayah tentang orang-orang yang sudah meninggal. Misalnya bertanya tentang mertuanya, tetangga dan saudara lain yang sudah tidak ada. Kejadian-kejadian semacam itu cukup sering terjadi dan menyebabkan timbulnya pertengkaran antara ayah dan ibu.Ibu sering merasa tersinggung dan marah saat ayah mengingatkan atau memberi penjelasan, terutama tentang orang-orang yang sering ditanyakan oleh ibu.

Tiga tahun berlalu, kondisi ingatan ibu semakin tidak baik.Ibu masih dapat beraktifitas setiap hari seperti mandi, buang air, menyiapkan makanan untuk ayah, berkebun (kegiatan yang sangat disukai ibu), dan beberapa kegiatan harian lainnya.Namun, ibu sudah tidak dapat menyimpan uang dan pergi keluar sendiri. Ayah sudah tidak pernah lagi memberikan gajinya secara utuh kepada ibu. Ia memutuskan untuk memberi ibu uang belanja setiap hari serta menemani setiap kali ibu pergi belanja ke warung. Suatu hari, ibu keluar rumah tanpa sepengetahuan ayah dan kembali dengan beberapa luka di tangan dan kaki. Tetangga yang mengantar mengatakan bahwa ia bertemu dengan ibu di ujung desa dengan kondisi tangan kaki yang terluka. Ibu mengatakan bahwa ia terjatuh.Sebagai anak yang masih belum berkeluarga, kemudian kedua anak perempuan mereka ( $\mathrm{L}$ dan $\mathrm{G}$ ) berinisiatif untuk mengajak ibu berobat dan tinggal di Malang.

Seminggu tinggal di Malang bersama kedua puterinya, keadaan ibu tidak semakin baik. Kedua puterinya mengeluhkan bahwa ibu sering gelisah dan sulit tidur baik siang mapun malam hari, selalu bertanya dimana ayah dan kapan ayah datang, kapan ia akan pulang, sering marah-marah dan menangis saat tersinggung, mengomel dan selalu berusaha membuka pintu di malam hari. Merekan merasa bingung dan meminta ayah untuk segera datang dan berharap ayah mau tinggal di Malang agar mereka dapat lebih mudah merawat kedua orangtua. Namun sang ayah tidak mau. Ia keberatan untuk tinggal di Malang. Ayah mengatakan bahwaia tidak suka tinggal di Malang karena ia tidak tahu harus mengisi hari dengan melakukan apa. Di rumahnya, ayah menyukai aktifitas ke sawah setiap hari, pekarangan rumah yang luas dan penuh dengan pepohonan, merawat kolam ikan dan lain sebagainya. Sementara di Malang, rumah anaknya tidak cukup besar dan minim pekarangan, sehingga tidak dapat merawat pohon apapun di halaman rumah. Ayahbersikeras untuk tetap di Pare dan merelakan ibu untuk tinggal di Malang. Ia berjanji kepada kedua puterinya bahwa sebagai gantinya, ia akan sering menjenguk ibu. Namun, kondisi ibu yang memburuk terpaksa membuat ayah harus segera ke Malang.

L dan G merasa kecewa kepada ayah karena tidak mau mengerti keinginan mereka.Mereka berharap ayah mereka bersedia untuk pindah ke Malang, menemani ibu, dan sekaligus mempermudah mereka dalam merawat kedua orangtuanya.Namun ayah tetap kukuh pada pendiriannya.Hal tersebut menimbulkan ketegangan dan kesalahpahaman antara ayah dan anak.Komunikasi ayah-anak menjadi lebih buruk dari sebelumnya.Padahal komunikasi merupakan komponen penting dalam hubungan antara orangtua dan anak (Offrey \& Rinaldi, 2014). Sementara kondisi ibu di Malang semakin memburuk dan membutuhkan penanganan segera.

Pola komunikasi yang terbangun dalam keluarga tersebutselama ini mengarah pada 
bentuk indirect communication yang menyebabkanmasing-masing anggota keluarga mengalami kegagalan dalam memahami maksud dan keinginan anggota keluarga yang lain (Luciana et al., 2012). Termasuk untuk mencari jalan keluar dalam memberikan penanganan terbaik untuk ibu. Alur permasalahan klien dapat diringkas pada Gambar 1.

Diagnosis dan Prognosis

\section{Diagnosis}

Berdasarkan uraiaan kasus, hasil asesmen dan rujukan yang ada di Diagnostic and Statistical Manual of Mental Disorder Fifth Edition (DSM-V), diagnosis untuk permasalahan klien memenuhi kriteria diagnostik Parent-Child Relational ProblemV61.20 (Z62.820) dengan

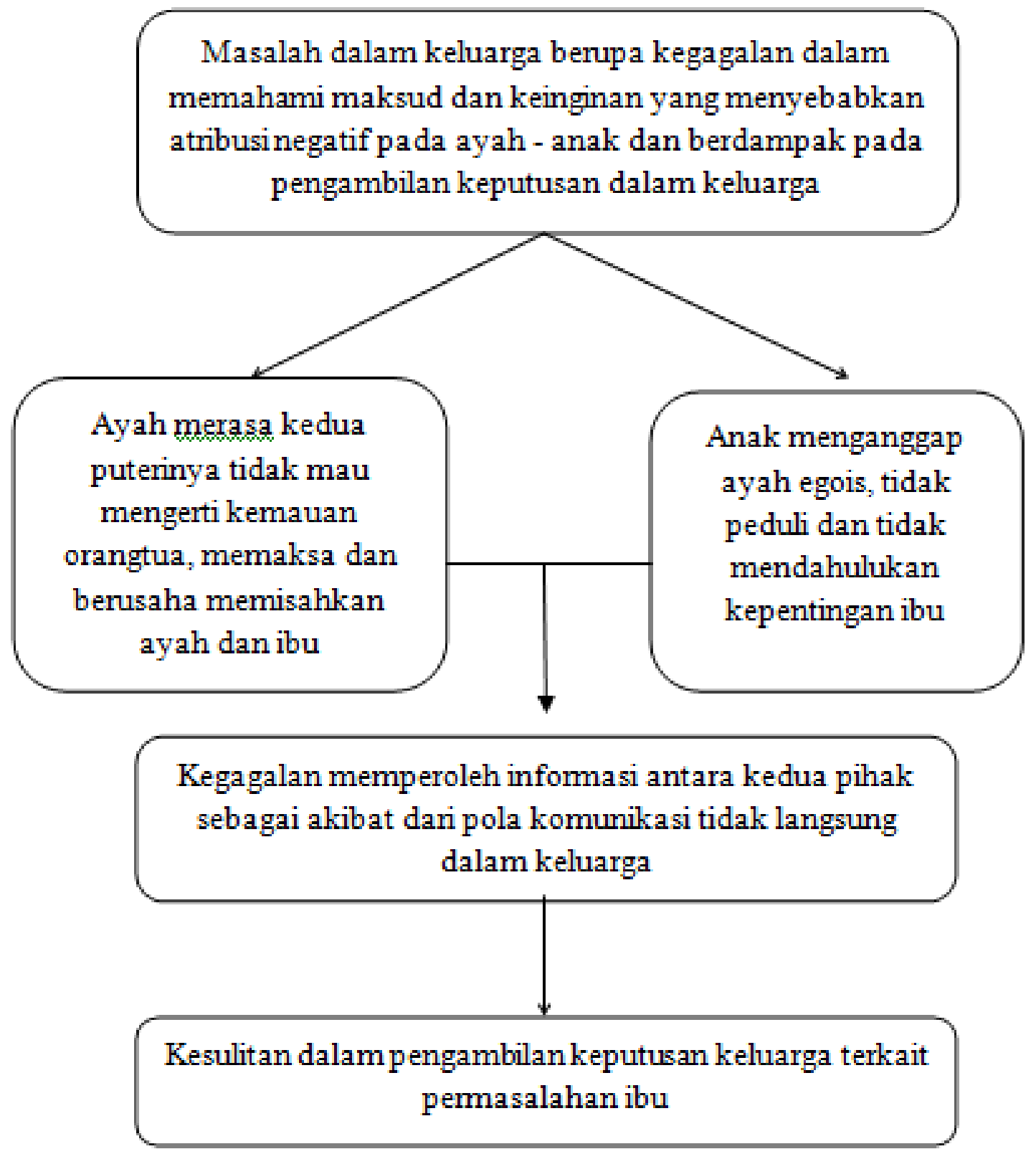

Gambar 1. Permasalahan subjek. 
permasalahan pada komunikasi yang menyebabkan pandangan orang tua dan anak berbeda yang kemudian menimbulkan atribusi negatif pada ayah dan anak.

\section{Prognosis}

Terapis memperkirakan keberhasilan intervensi untuk keluarga ini adalah positif/ baik.Ayah dan kedua puterinya memiliki keinginan dan usaha untuk berusaha mencari jalan keluar dengan mengikuti intruksi yang diberikan terapisberdasarkan kontrak kerjasama. Ayah-anak tersebut juga sangat kooperatif dan saling memberi ruang untuk mengemukakan apa yang ingin disampaikan.

\section{Intervensi}

Penanganan pada kasus ini menggunakan solution focused therapy (SFT). SFT merupakan salah satu bentuk terapi yang dikembangkan untuk mengidentifikasi berbagai permasalahan, baik pada individu maupun keluarga, misalanya masalahkomunikasi dan interaksi anggota keluarga (Castro \& Guterman, 2008; Gingerich \& Eisengart, 2000). SFT merupakan terapi yang berfokuspada bagaimana memahami sebuah penyebab suatu masalah, memahami pola dalam masalahyang terjadi sehingga menemukan solusi atas permasalahan yang dialami (Trepper et al., 2006). Pendekatan pada SFT dapat memungkinkan seseorang untuk membangun sebuah perubahandimasa depan atau yang akan datang.

Asumsi utama dalam SFT bahwa setiap klien menginginkan perubahan dalam masalah yang dialami dan mereka memiliki kapasitas untuk membayangkan perubahan, sehingga setiap anggota dalam terapi ini dapat melakukan dan membuat perubahan untuk dirinya dan orang lain (Castro \& Guterman, 2008; Gingerich \& Eisengart, 2000; Trepper et al., 2006). Melalui teknik ini juga klien akan diarahkan untuk berfokus pada kekuatan dan ketahanan serta mengingatkan kembali akan solusi sebelumnya dari permasalahan yang serupa, lalu kemudian, melalui serangkaian intervensi, terapis akan mendorong klien untuk melakukan lebih dari keberhasilan yang pernah dilakukan sebelumnya (Trepper et al., 2006). Terapis dan klien berkolaborasi untuk mengindentifikasikan suatu masalah dan apa tujuan bersama yang ingin dicapai. Dengan mendefinisikan masalah maka masalah dalam sebuah keluarga akan dikonsepkan dan membantu keterampilan coping yang lebih efektif.

Penanganan pada kasus permasalahan keluarga ini menggunakan terapi SFT dengan alasan masalah yang dialami keluarga saat ini merupakan salah satu permasalahan yang muncul sebagai akibat dari tidak efektifnya komunikasi antar klien.Sebagaimana asumsi dasar dari teknik ini, terapis meyakini bahwa klien memiliki kemampuan untuk mengetahui apa yang terbaik untuk mereka dan memiliki daya untuk merencanakan cara menuju tujuan tersebut secara efektif (Trepper et al., 2006). Tujuan dari penggunaan teknik SFT adalah mengubah carakomunikasi yang terjalin antar klien yang selama ini kurang mampu berkembang dengan baik karena kualitas hubungan dan tidak adanya kesempatan untuk berinteraksi antar anggota dalam keluarga sehingga dengan SFT akan membentuk pola komunikasi yang lebih baik dan positif dan mencari solusi untuk memecahkan berbagai masalah keluarga. Adapun prosedur sesi dari SFT yang digunakan dalam kasus ini dilakukan dalam lima (5) sesi yaitu:

Sesi pertama: Building Raport dan Penggalian Masalah. Pada sesi ini terapis membangun raport dan menumbuhkan kepercayaan pada setiapanggota keluarga dan memberikan gambaran akan terapi yang dilakukan dengan hadirnya ibu dan anak. Kegiatan ini bertujuan untuk memotivasi klien agar bersedia mengikuti proses terapi hingga akhir sesi.Penggalian masalah pada sesi ini lebih banyak menggunakan teknik normalization dan presuppositional questioning.

Hasil : pada sesi ini tidak membutuhkan waktu yang lama bagi anak untuk menceritakan apa yang terjadi, apa yang menjadi keluhan dan bagaimana perasaan mereka. Mereka juga 
menceritakan upaya-upaya yang telah mereka lakukan selama ini. Sementara ibu yang saat itu turut hadir lebih banyak diam, tersenyum dan menjawab pertanyaan yang diajukan baik oleh terapis maupun kedua anaknya.Pada sesi ini juga dilaksanakan penandatanganan informed consent oleh anak.

Sesi kedua: Komunikasi Masalah, Pemberian Tugas. Pada sesi ini, kedua anak datang bersama ayah dan ibu.Agenda utama sesi ini adalah untuk mengkomunikasikan temuan terkait masalah yang mereka hadapi.Terapis terlebih dahulu membangun rapport dengan ayah dan melakukan penggalian masalah berdasarkan perspektif ayah. Kemudian, pada sesi ini terapis menjelaskan aturan terapi yang salah satunya adalah masing-masing dapat mengutarakan pendapatnya dan akan mendapatkan giliran secara adil.Tugas yang diberikan pada sesi ini berupa kesepakatan masing-masing anggota keluarga (ayah-anak) untuk mengobservasi apa yang terjadi dalam keluarga, apa yang masing-masing anggota keluarga harapkan dan apa yang perlu dilakukan.

Hasil : ayah menandatangani lembar informed consent kemudian penggalian masalah pada ayah menggunakan teknik yang sama, yaitu normalization dan presuppositional questioning. Ayah mengatakan bahwa ia sudah melakukan apa yang paling ia rasa benar. Meski ia juga nampak kecewa karena keputusannya untuk menahan ibu tetap bersamanya bukan keputusan yang tepat untuk kondisi ibu saat ini. Anak berusaha untuk menyampaikan apa yang mereka maksud dengan cara yang tenang. Masing-masing anggota keluarga mencoba untuk mengerti kebutuhan dan harapan anggota keluarga lainnya.Cara bicara ayah sudah mulai melunak dalam menyampaikan keinginannya.Sesi ini berakhir dengan pemahaman pada masing-masing klien tentang pentingnya memperbaiki komunikasi dimana baik ayah maupun anak sepakat untuk memperbaiki cara komunikasi untukmencari jalan keluar demi mendahulukan kebutuhan ibu.

Sesi ketiga: Evaluasi Perubahan dan Terminasi. Pada sesi ini evaluasi dilakukan untuk melihat sejauh mana solusi yang telah dilakukan oleh masing-masing anggota keluarga.Terapis mengevaluasi apakah solusi yang telah ditemukan dapat diterapkan untuk mengubah komunikasi yang terjalin antar anggota keluarga, serta melihat bagaimana kekurangan dan kelebihan masing-masing anggota dalam melaksanakan tugasnya tersebut.

Hasil : pada sesi ini target terpenuhi, ayah serta kedua puterinya berhasil menjalankan kesepakatan mereka sebelumnya. Ayah mulaimemahami bahwa keinginan kedua puterinya meminta merawat ibu di Malang semata-mata karena bakti seorang anak terhadap ibu. Ayah juga menyadari bahwa anak-anaknya tersebut sangat menyayangi mereka dan ingin tinggal dan merawat mereka di usia senjanya. Anak juga memahami bahwa kedua orangtuanya tidak mungkin untuk dipisahkan, dalam keadaan apapun.Mereka juga kini mengerti, bahwa yang dibutuhkan baik oleh ibu maupun ayah adalah rasa nyaman dari hidup bersama serta hidup di tempat yang membuat mereka nyaman yaitu di rumah mereka di Pare.Dalam sesi ini, anak menangis dan meminta maaf kepada ayah dan ibu sambil memeluk mereka.Ayah juga tampak terharu dan membalas pelukan kedua putrinya.Sementara ibu yang sejak awal hanya tersenyum turut menitikkan air mata dan memeluk kedua putrinya.

Kemudian sesi terapi ditutup dan masing-masing anggota keluarga didorong untuk tetap mempertahankan cara komunikasi yang telah dipelajari tersebut dalam setiap keadaan, terutama yang membutuhkan pengambilan keputusan keluarga.

Sesi keempat: Follow Up. Sesi follow up dilakukan oleh terapis dengan menghubungi anak dan menanyakan kabar ibu. Anak melaporkan bahwa saat ini ibu sedang dalam masa menunggu pemeriksaan dari dokter terkait demensia yang dideritanya. Selama menunggu ayah dan ibu yang berada di Pare secara rutin dijenguk baik oleh kedua puterinya maupun anak-anak yang lain. Ibu juga menunjukkan reaksi emosi yang lebih stabil dan tenang.Ia tetap menjalani kehidupannya seperti biasa, berbelanja, menyiapkan makanan untuk ayah dan menemani ayah ke sawah. Serta tentu saja tetap berkebun.Ayah juga menunjukkan keseriusannya untuk 
terus mendampingi ibu kemanapun dan dalam kegiatan apapun.Anak mengucapkan banyak terimakasih kepada terapis.

\section{Hasil dan Pembahasan}

\section{Hasil}

Setelah melalui seluruh rangkaian proses intervensi, terdapat perubahan bentuk komunikasi yang lebih adaptif antara ayah dan anak-anak. Sebelum terapi dilakukan ayah dan kedua puterinya tidak memiliki komunikasi yang positif, sehingga menimbulkan pandangan dan kesalahpahaman yang pada akhirnya memunculkan atribusi negatif antara kedua pihak.Adapun hasil dari intervensi dapat diketahui melalui Tabel 1.

Tabel 1. Perubahan Intervensi Sebelum Intervensi Setelah Intervensi Ayah berpikir anak memaksakan kehendak dan ingin memisahkan ayah dan ibu Ayah memahami bahwa anak hanya menginginkan yang terbaik untuk ibu Anak merasa ayah egois dan tidak memprioritaskan kebutuhan ibu Anak menyadari bahwa ayah hanya tidak ingin tinggal terpisah dengan ibu Ayah dan anak tidak menemukan cara yang tepat untuk mencari jalan keluar pada permasalah ibu Komunikasi ayah-anak yang mulai membaik memberikan hasil dimana keluarga (ayah-anak) menemukan solusi terbaik untuk permasalah ibu

Perubahan ini dapat diketahui dari tercapainya sebuah keputusan keluarga terkait penanganan untuk permasalahan ibu.Seluruh anggota keluarga telah menyetujui untuk melakukan perawatan terhadap ibu namun juga tidak mengurangi kenyamanan ibu dan ayah. Keluarga memutuskan ibu dan ayahakan tetap tinggal di Pare sesuai dengan keinginan ayah. Mereka hanya akan ke Malang saat perlu menemui dokter. Ayah merasa lebih senang karena tetap dapat beraktifitas sebagaimana biasa juga menjadi lebih tenang karena ibu tetap berada di sampingnya. Ayah berkomitmen untuk terus memperhatikan dan menemani kemanapun ibu pergi. Sementara di sisi lain, anak menyadari bahwa kedua orangtuanya tidak dapat berpisah meski dalam kondisi apapun. Mereka memilih mengalah dan berkomitmen untuk lebih sering menjenguk kedua orangtuanya dan menemani mereka di sana.

Keberhasilan intervensi juga dapat diketahui dari hasil follow up dimana anak melaporkan bahwa kondisi ibu justru menunjukkan perkembangan yang positif meski belum mendapatkan perawatan dari dokter spesialis. Ibu lebih tenang, tidak lagi susah tidur, tetap menjalankan aktifitas harian seperti berbelanja, menyiapkan makanan, merawat tanaman di halamannya dan menemani ayah ke sawah. Ayah juga menjalankan komitmennya untuk terus menemani ibu kemanapun, bahkan berbelanja di tukang sayur.

Tabel 1. Hasil dari intervensi

\begin{tabular}{llll}
\hline Sebelum Intervensi & Setelah Intervensi & \\
\hline $\begin{array}{l}\text { Ayah berpikir anak memaksakan } \\
\text { kehendak dan ingin memisahkan ayah }\end{array}$ & $\begin{array}{l}\text { Ayah memahami bahwa anak hanya } \\
\text { menginginkan yang terbaik untuk ibu }\end{array}$ \\
dan ibu & & & \\
Anak merasa ayah egois dan tidak & Anak menyadari bahwa ayah hanya tidak \\
memprioritaskan kebutuhan ibu & $\begin{array}{l}\text { ingin tinggal terpisah dengan ibu } \\
\text { Ayah dan anak tidak menemukan cara }\end{array}$ & $\begin{array}{l}\text { Komunikasi ayah-anak yang mulai membaik } \\
\text { memberikan hasil dimana keluarga } \\
\text { yang tepat untuk mencari jalan keluar } \\
\text { pada permasalah ibu }\end{array}$ & $\begin{array}{l}\text { (ayah-anak) menemukan solusi terbaik } \\
\text { untuk permasalah ibu }\end{array}$ \\
\hline
\end{tabular}




\section{Pembahasan}

Berdasarkah hasil intervensi yang telah dilakukan sebelumnya, komunikasi dalam keluarga menunjukkan perubahan yang positif.Perubahan positive yang dicapai pada pola komunikasi berfokus pada solusi yang dilakukan untuk menyelesaikan permasalahan dengan memberikan tugas-tugas pada masing-masing anggota keluarga (Gingerich \& Eisengart, 2000). Beberapa tugas yang diberikan kepada keluarga tersebut selain mengidentifikasi permasalahan apa yang sebenarnya terjadi dalam keluarga adalah untuk berusaha mengobservasi dan memahami apa yang terjadi dalam keluarga, apa yang masing-masing anggota keluarga harapkan dan apa yang perlu dilakukan oleh seluruh anggota keluarga.

Permasalahan indirect communication yang terjadi pada keluarga menyebabkan tidak tersampaikannya informasi secara utuh yang berdampak pada timbulnya kesalahan dalam mempersepsi informasi tersebut (Offrey \& Rinaldi, 2014). Baik ayah maupun kedua puterinyaselama ini tidak menyangka bahwa cara komunikasi mereka bukan cara yang tepat, terutama dalam menyelesaikan permasalahan yang terjadi dalam keluarga. Jarak tempat tinggal yang cukup jauh semakin tidak mendukung komunikasi positif dalam keluarga mereka.Mereka terjebak dalam dugaan-dugaan dan persepsi yang lebih mengarah kepada persepsi negatif yang kemudian menimbulkan atribusi negatif baik pada diri ayah maupun anak.

Setelah mengikuti seluruh sesi terapi menggunakan teknik solution focused therapy, ayah dan kedua puterinya berhasil untuk mengembangkan solusi untuk membuat komunikasi dan kualitas hubungan menjadi lebih baik. Keluarga tersebut juga berhasil menemukan solusi untuk permasalahan keluarga saat itu, yaitu perawatan untuk ibu.Solution focused therapy merupakan intervensi yang cocok digunakan untuk mengatasi permasalahan dalam keluarga sehingga teknik ini dapat berjalan dengan baik pada kasus keluarga tersebut. Teknik solution focused therapy berasumsi bahwa setiap klien memiliki bakat dan sumber daya dalam menyelesaikan permasalahannya sendiri untuk mencapai sebuah solusi (Gingerich \& Eisengart, 2000). Selain itu, penekanan dari solution focused therapy adalah keyakinan bahwa perubahan sekecil apapunakan mempengaruhi sistem dalam keluarga.

Membaiknya komunikasi dalam keluarga tersebut menjadi hasil dari rangkaian terapi ini.Melalui komunikasi antar anggota keluarga yang semakin positif, solusi untuk setiap permasalahan keluarga menjadi lebih mudah untuk di dapat. Konflik keluarga terkait perawatan untuk ibu dapat terselesaikan seiring dengan semakin adaptifnya komunikasi antara ayah dan kedua puterinya, yang sesuai dengan asumsi solution focused therapy dimana perubahan kecil mampu menimbulkan dampak yang signifikan dalam keluarga (Gingerich \& Eisengart, 2000; Trepper et al., 2006).

Keluarga tersebut kini menyadari pentingnya keterbukaan dalam komunikasi dan bahwa apa yang terjadi pada keluarga mereka merupakan kesalahan seluruh anggota keluarga yang selama ini mengembangkan komunikasi yang salah. Kesalahan dalam komunikasi tentu berdampak luas terutama dalam kualitan hubungan antara anggota keluarga. Orangtua yang mampu mengajarkan komunikasi langsung dan terbuka kepada anak-anaknya secara tidak langsung membuat hubungan antara orangtua-anak terserbut menjadi lebih berkualitas (Davidson \& Cardemil, 2009; Luciana et al., 2012; Offrey \& Rinaldi, 2014). Pada kasus keluarga tersebut, ayah kini semakin memahami bahwa kedua putrinya sangat menyayangi orangtua dan hanya menginginkan yang terbaik untuk ibu mereka, begitu juga untuk dirinya.Sementara bagi anak, membaiknya komunikasi dengan ayah membuat mereka menyadari bahwa ayah mereka sangat mencinta ibu mereka, dan selama ini mereka salah dalam menilai sikap ayah.

\section{Simpulan}

Solution focused therapy efektif untuk memperbaiki pola komunikasi keluarga yang khususnya pada kasus ini komunikasi antara ayah dan anak. Hal ini terlihat pada bagaimana 
mereka menemukan solusi dari masalah yang dialaminya.Pandangan yang saling berbeda dan saling mengetahui keinginan masing-masing memunculkan solusi yang telah mereka temukan sendiri.Solusi yang ditemukan mampu diterapkan dalam kehidupan sehari-hari sehingga mereka mampu melakukan perubahan pola komunikasi dan adanya kesempatan untuk saling berinteraksi.

\section{Referensi}

Castro, S. De, \& Guterman, J. T. (2008). Solution-Focused Therapy for families coping with suicide. Journal of Marital and Family Therapy, 34(1), 93-106.

Davidson, T. M., \& Cardemil, E. V. (2009). Parent-Child Communication and Parental Involvement in Latino Adolescents. Journal of Early Adolescence, 29(1), 99-121.

Gingerich, W. J., \& Eisengart, S. (2000). Solution-Focused Brief Therapy: A Review of the Outcome Research*, 39(4), 477-498.

Leiber, M. J., Mack, K. Y., \& Featherstone, R. A. (2009). Family Structure, Family Processes , Economic Factors , and Delinquency Similarities and Differences by Race and Ethnicity. Youth Violence and Juvenile Justice, $7(2), 79-99$.

Luciana, P., Constantineanu, C., Ielics, B., \& Popa, D. (2012). The role of communication in the parent-child interaction. Procedia - Social and Behavioral Sciences, 46, 904-908. https://doi.org/10.1016/j.sbspro.2012.05.221

Offrey, L. D., \& Rinaldi, C. M. (2014). Parent - child communication and adolescents ' problem-solving strategies in hypothetical bullying situations. International Journal of Adolescence and Youth, (January). https://doi.org/10.1080/02673843.2014.884006

Trepper, T. S., Dolan, Y., Mccollum, E. E., \& Nelson, T. (2006). Steve de Shazer and the future of Solution-Focused Therapy. Journal of Marital and Family Therapy, 32(2), 133-139. 